\title{
ARTIGO - COMO CRIANÇAS ALFABETIZADAS COM O MÉTODO FÔNICO RESOLVEM TAREFAS QUE AVALIAM A CONSCIÊNCIA FONÊMICA?
}

SILVIA DE SOUSA AZEVEDO ARAGÃO'

ORCID: https://orcid.org/0000-0003-4684-4375

ARTUR GOMES DE MORAIS

ORCID: https://orcid.org/0000-0002-2325-0315

I Universidade Federal de Pernambuco, Centro de Educação, Recife, PE, Brasil.

Silvia de S. A. Aragão - Mestre em Educação e doutoranda pela Universidade Federal de Pernambuco (UFPE). E-mail:<silvias.a@hotmail.com $>$.

Artur G. de Morais - Doutorado em Psicologia pela Universidad de Barcelona (1996). Professor titular do Centro de Educação da Universidade Federal de Pernambuco. E-mail:<agmorais59@gmail.com>.

RESUMO: A pesquisa discute a relação entre várias habilidades de consciência fonêmica e os desempenhos de leitura apresentados por 20 crianças concluintes do primeiro ano, que tinham alcançado uma hipótese alfabética e eram ensinadas em escolas públicas com um método fônico. Elas foram submetidas a nove tarefas de consciência fonêmica e a três tarefas de leitura (de palavras, de frases e de texto). $\mathrm{Na}$ maioria das tarefas de consciência fonêmica houve um desempenho médio inferior ou igual a $60 \%$. Ao lerem, os aprendizes revelaram um bom desempenho apenas na leitura de palavras, que apresentou correlação com poucas habilidades de consciência fonêmica. As análises qualitativas revelaram que as crianças pensavam predominantemente sobre letras ou sílabas e quase não verbalizavam fonemas. Nossas evidências levam a questionar a relevância de um ensino que priorize o treino isolado da pronúncia de fonemas como requisito para a aprendizagem da leitura e da escrita em Português.

Palavras-chave: Consciência fonêmica. Aprendizado do sistema de escrita alfabética. Alfabetização. Método fônico.

HOW DO CHILDREN TAUGHT WITH A PHONIC METHOD ANSWER TASKS WHICH EVALUATE PHONEMIC AWARENESS?

ABSTRACT: We discuss the relationships between several abilities of phonemic awareness and reading performance showed by 20 children who were concluding first grade, having understood the alphabetic principle, and who were taught with phonic methods in public schools. They answered nine phonemic awareness tasks and three reading tasks (words, phrases and 
text). In most phonemic awareness tasks average performance was equal or less than $60 \%$. Children only read well in the words task and it correlated with few abilities of phonemic awareness. Qualitative analysis showed that children thought mainly about letters or syllables and hardly could pronounce phonemes. Our data question the relevance of methods of literacy teaching which emphasize the pronunciation of isolated phonemes as a requisite for the learning of reading and writing in Portuguese.

Keywords: Phonemic awareness. Learning of alphabetic writing. Literacy instruction. Phonic method.

\section{INTRODUĈ̣̃O}

Registramos, há alguns anos, a seguinte cena numa sala de aula de primeiro ano do ensino fundamental. Nela, P é a professora e A é um aluno a quem a docente se dirigia mais diretamente:

P-Gente, qual é a letra que nós estamos aprendendo o som?

Alunos: $\mathrm{R}$

P-Agora é só João! João vai falar para mim esse som. Eu quero ouvir se João está falando certinho. A- Eu sei não!

P-Eu ouvi João falando meio estranho. Qual é o som que a gente está procurando, João?

A. Eu não sei!

P- Não sabe!? Mas vai ter que aprender a falar! $A$ - Eu não quero aprender, eu não sei! P- Fale o som! A- Nããão!

P- Fale do jeito que você sabe! A- Eu não sei de nenbum jeito! P- Mas vai ter que aprender João! Olha, vê! Quando a gente vai ler a palavra, a gente tem que dižer o som que está nela! Então, se João não conseguir falar o som / R/, como

é que ele vai conseguir ler?

A- Eu já sei ler!

P- Então se você sabe ler, você sabe dizer o som! JO ÃO-Sei não!

(grifo nosso) 
João era aluno em uma das duas turmas de primeiro ano em que a investigação aqui descrita foi realizada. De fato, no final do ano letivo, ele era um dos aprendizes que, tendo sido ensinado com base num método fônico, já tinha alcançado uma hipótese alfabética e podia ler e escrever palavras, usando várias letras com seus valores convencionais. Nossa pergunta principal de pesquisa, ao nos aproximarmos daquelas crianças e de suas professoras foi: Como crianças alfabetizadas por um método fônico que treina diversas habilidades fonêmicas resolvem tarefas que avaliam aquelas habilidades?

Num estudo prévio, Aragão e Morais (2013) exploraram o mesmo tema. Numa cidade em que os professores eram obrigados a usar o método fônico Alfa e Beto, analisaram o desempenho de 15 crianças que, ao iniciar o segundo ano do ensino fundamental, já conseguiam ler e escrever palavras com autonomia. Elas foram submetidas a onze tarefas de consciência fonêmica e seus desempenhos médios foram bem mais baixos do que poder-se-ia esperar, considerando a didática de alfabetização adotada por aquela rede pública de ensino. Embora tenham se saído bem na tarefa de Identificação de palauras com o mesmo fonema inicial (81\% de acertos) e razoavelmente nas tarefas de Producão de palavras a partir da escuta de um fonema e de Contagem de fonemas nas palavras (75\% e 73\% de acertos médios, respectivamente), em todas as demais habilidades seus rendimentos médios foram iguais ou inferiores a 35\%. Revelaram, ademais, muita dificuldade nas situações que mediam as habilidades de Adição e Subtração de fonemas iniciais em palavras inventadas (15\% e 14\% de acertos, apenas) e não conseguiram pontuar na tarefa de Segmentação das palavras em fonemas, na qual deveriam pronunciar, em vOz alta e sequencialmente, os fonemas de palavras curtas como "lua" e "gato".

Como é próprio da lógica experimental, poder-se-ia indagar: quem garante que as docentes que ensinaram àquelas crianças do estudo agora mencionado, no ano anterior, de fato, seguiam a proposta do método fônico e realizavam, com seus alunos, todas as atividades de promoção da consciência fonêmica nele sugeridas? A fim de responder a essa pergunta é que fizemos a presente investigação, tendo o cuidado de selecionar uma amostra de aprendizes cujas docentes, no dia a dia, buscavam seguir o que era prescrito pelos autores do mesmo método fônico.

Antes de descrever os procedimentos metodológicos e apresentar os resultados, vamos revisitar alguns estudos que, desde o final dos anos 1970, vêm alimentando o debate sobre as relações entre o desenvolvimento da consciência fonológica (aí incluída a consciência fonêmica) e o aprendizado da leitura e da escrita. 


\section{REVENDO ALGUMAS EVIDÊNCIAS SOBRE AS RELAC̄̃̃ES ENTRE CONSCIÊNCIA FONOLÓGICA E ALFABETIZAC̣ÃO}

O conceito de consciência fonológica vem sendo objeto de debate desde a década de 1970 e vários são os consensos e dissensos que giram em torno do tema.

Após as controvérsias iniciais, que diziam respeito à consciência fonológica ser causa ou consequência da alfabetização (cf. MORAIS, J. et al. 1979; BRADLEY; BRYANT, 1983), elaboramos na década seguinte dois acordos básicos:

I) A consciência fonológica passou a ser vista como uma "constelação", isto é, um conjunto de habilidades que permitem ao ser humano operar metafonologicamente sobre segmentos orais das palavras como sílabas, rimas e fonemas (GOUGH; LARSON; YOPP, 1995). Além da diversidade dos segmentos sonoros implicados e dos efeitos da posição em que se encontram nas palavras, também descobrimos que a complexidade das tarefas metafonológicas variava conforme as diferentes operações implicadas (identificar, contar, segmentar, adicionar, subtrair, transpor, sintetizar etc.) conforme o tamanho dos vocábulos e do fato dos vocábulos em foco serem palavras reais ou inventadas (cf. MORAIS, 2019);

II) As relações entre o desenvolvimento da consciência fonológica - aí envolvidas as habilidades fonêmicas - e o aprendizado da leitura e da escrita seriam interativas (cf. STANOVICH, 1986), de modo que, à medida que os indivíduos avançam em seu processo de alfabetização, mais habilidades de consciência fonológica revelariam e, vice-versa. Isto é, o desenvolvimento das habilidades metafonológicas também definiria os avanços na apropriação das convenções grafemafonema e fonema-grafema da escrita alfabética que estariam aprendendo. Neste processo interativo, a tendência seria certas habilidades fonêmicas dependerem mais da apropriação da notação alfabética, enquanto tarefas envolvendo sílabas e rimas desenvolver-se-iam mais cedo, mesmo antes dos aprendizes conseguirem ler palavras gerativamente.

Tardamos, porém, a enfrentar outra importante discussão em torno do tema, que tem a ver com a maior opacidade ou transparência das relações entre fonemas e grafemas, em cada língua. Como já apontava Vernon (1997), a natureza particular de cada língua impõe restrições ao tipo de análise que as crianças podem fazer sobre ela. 
Assim, uma habilidade fonológica que é mais fácil em uma língua, pode ser mais difícil em outra. Nessa perspectiva, interpretamos que certas habilidades necessárias para a alfabetização em uma língua com notação alfabética mais transparente poderiam ser menos complexas que as necessárias para línguas com ortografias opacas(cf. MORAIS, A. G. 2019). Soares (2016) faz uma aprofundada revisão do tema, demonstrando, inclusive, a necessidade de reconhecermos as especificidades das relações entre fonemas e grafemas do português brasileiro, quando comparadas às equivalentes do português europeu. Adotando uma perspectiva construtivista, que trata a escrita alfabética como um sistema notacional e não como um código (cf. por exemplo, MORAIS, A. G. ; LIMA, 1989), assumimos, desde os anos 1980 a perspectiva de que o desenvolvimento de habilidades de consciência fonológica é uma condição necessária, mas não suficiente, para um aprendiz compreender o sistema de escrita alfabética (doravante, SEA) e se apropriar de suas convenções. Já desde o início do atual milênio, Morais (2004, 2015) buscou relacionar as habilidades de consciência fonológica à evolução das hipóteses de escrita das crianças e, sistematicamente, obteve evidências semelhantes que revisaremos a seguir.

Considerando a questão de pesquisa que guiou o trabalho descrito neste artigo, na presente seção, ao revisar aqueles estudos feitos por Morais e por outros pesquisadores com crianças brasileiras, priorizaremos o que se tem descoberto sobre o desempenho que os aprendizes revelam ao resolver tarefas de consciência fonêmica e quais comparações podem ser feitas em relação ao rendimento que expressaram em tarefas envolvendo consciência metafonológica de rimas ou sílabas.

Morais, A. G. (2004; 2015) realizou estudos longitudinais com crianças brasileiras que cursavam a $1^{\circ}$ série de uma rede pública. Em ambas as pesquisas houve a aplicação de uma tarefa de escrita de palavras sob ditado e algumas tarefas que mediam diversas habilidades fonológicas no nível da sílaba e do fonema. As quatro tarefas no nível do fonema eram: Segmentação de palauras em fonemas e Contagem de fonemas nas palavras, além das que mediam Identificação e Produção de palavras com o mesmo fonema inicial. Ao analisar os dados obtidos, o autor sempre constatou que as crianças com hipóteses mais elaboradas de escrita (silábico-alfabéticas e alfabéticas) apresentavam melhor desempenho em diferentes tarefas de reflexão fonológica, especialmente naquela que solicitava a Identificação de palavras que comeşam com o mesmo fonema. No entanto, duas evidências chamavam a atenção: i) na tarefa de Produção de palauras com o mesmo fonema inicial, mesmo após dois itens de exemplo e dois de treino, quando alertadas de que deviam pensar apenas no "sonzinho 
pequeninho do começo", as crianças que já tinham compreendido como o SEA funciona tendiam a dizer palavras que continham a sílaba inicial completa da palavra-estímulo dita pelo adulto; ii) as tarefas de segmentação oral e contagem de fonemas eram extremamente difíceis, inclusive para os alunos no nível alfabético de escrita, que tendiam a pronunciar ou contar, letras, sílabas ou uma mistura dessas unidades, raramente pronunciando fonemas em voz alta.

Leite (2011) também realizou uma pesquisa longitudinal em duas escolas públicas brasileiras, com crianças da $1^{\mathrm{a}}$ série (atual $2^{\circ}$ ano do ensino fundamental), com diferentes hipóteses de escrita, a fim de identificar a importância de habilidades metafonológicas na aprendizagem do SEA. Os resultados mostraram, assim como os de Morais, A. G. (2004; 2015) que as tarefas envolvendo sílabas iniciais das palavras foram mais fáceis para aprendizes de todos os níveis, enquanto, mais uma vez, mesmo os que já tinham alcançado uma hipótese alfabética apresentaram mais dificuldade em certas habilidades envolvendo consciência fonêmica (segmentação, contagem e produção de palavras com mesmo fonema inicial).

Mousinho e Correa (2009) estudaram 20 crianças brasileiras não-leitoras e 15 leitoras. Além da leitura de 24 palavras, e do julgamento de palavras com rimas e sílabas iniciais iguais, as pesquisadoras aplicaram as seguintes tarefas fonêmicas: subtração de fonemas iniciais, mediais ou finais; síntese e segmentação fonêmica; identificação de palavras com os mesmos fonemas em posição inicial, medial e final; e transposição de fonemas em palavras. As autoras observaram que as atividades de síntese fonêmica, de segmentação e transposição fonêmica, mostraram-se extremamente difíceis para todas as crianças (índices de acertos inferiores a 20\%). Constataram, também, que, conforme a lógica psicométrica, as tarefas envolvendo Subtração do fonema inicial e Identificação de palavras com o mesmo fonema inicial apareciam com níveis de dificuldade "média" e de "difícil realização", respectivamente para os alunos leitores.

Santos e Maluf (2010), por outro lado, pesquisaram sobre os efeitos de um programa de intervenção em habilidades metafonológicas, dirigido a 90 crianças de diferentes turmas, que estavam no último ano da educação infantil. Houve tarefas de ditado e de leitura de palavras e a mensuração de seis habilidades metafonológicas (identificação da extensão fonológica de palavras, identificação de rima, identificação de aliteração, consciência de palavras, segmentação silábica, segmentação fonêmica). A pesquisa constou de três etapas: pré-teste, programa de intervenção e pós- 
teste. Os resultados indicaram o avanço dos alunos nas habilidades metafonológicas e na escrita de palavras, o que levou as autoras a defenderem a importância do programa para o desenvolvimento das habilidades apontadas e dessas para o desenvolvimento da alfabetização: "O reconhecimento por parte da criança, de que a fala é segmentada em palavras e que estas podem ser segmentadas em unidades menores, é um facilitador da alfabetização." (SANTOS; MALUF,2010, p. 67). Porém, como naquele estudo não fica claro em quais habilidades testadas os alunos apresentaram melhor desempenho, a defesa é de que as habilidades metafonológicas, de forma geral, seriam facilitadoras da alfabetização. Isto nos leva a indagar: será que todas realmente são?

Puliezi e Maluf (2012), num estudo posterior, investigaram as relações entre consciência fonológica, memória de trabalho fonológica e velocidade de nomeação e a aquisição inicial da leitura, com 28 crianças do $1^{\circ}$ ano do ensino fundamental. Como metodologia, o procedimento incluiu a aplicação individual de tarefas de leitura de palavras, identificação de rima e fonema inicial, segmentação de palavras em sílabas, repetição de dígitos, repetição de pseudopalavras e nomeação de figuras. De acordo com o desempenho na leitura de palavras, as crianças foram classificadas como leitoras boas, más e intermediárias. Os dados indicaram que somente os bons leitores apresentaram um desempenho mais alto nas tarefas de identificação de rima e fonema inicial, enquanto que tanto os bons como os maus leitores tiveram resultados semelhantes na tarefa de segmentação silábica. Considerando que a capacidade de ler palavras apresenta relação com a apropriação de todas ou a maior parte das características do sistema de escrita alfabética, os resultados indicam que as habilidades envolvendo rima e fonema inicial encontram-se mais próximas ao processo final da apropriação da escrita.

Cavalheiro, Santos e Martinez (2010) fizeram uma pesquisa buscando verificar se a consciência fonológica, principalmente as habilidades em consciência silábica e fonêmica, influenciavam a velocidade e o nível da leitura de textos. Participaram deste estudo 60 crianças, de 5 a 8 anos, matriculadas em escolas particulares de SalvadorBahia, que cursavam o $1^{\circ}$ ano do Ensino Fundamental. Foi aplicada a Prova de Consciência Fonológica (PCF, elaborada por CAPOVILLA e CAPOVILLA, 1998), contendo dez sub testes relativos às rima, aliteração, segmentação, síntese, manipulação e transposição silábica e fonêmicas e utilizaram, ainda, dois textos para avaliar o nível e velocidade de leitura em voz alta e silenciosa. Comparou-se e correlacionou-se estatisticamente o 
desempenho dos escolares na PCF com o nível e a velocidade de leitura. Foi observado que o nível de leitura acompanhava o desenvolvimento da consciência fonológica e que uma maior pontuação na PCF conferia uma maior velocidade de leitura.

Os resultados indicaram, porém, que haveria uma correlação positiva fraca entre a consciência fonológica, principalmente entre a consciência fonêmica e o nível e a velocidade da leitura. Nessa pesquisa, embora as pesquisadoras não o enfatizem, a habilidade fonêmica que apresentou mais baixo desempenho foi a segmentação de palavras em fonemas. As análises feitas levaram em conta a relação entre o desempenho entre leitura e consciência fonêmica de forma geral, o que dificulta entender se todas as habilidades metafonêmicas apresentavam a mesma relação com o desenvolvimento da leitura. Além disso, as autoras interpretaram que os aprendizes apresentavam um nível de consciência fonêmica inferior para sua faixa etária, desconsiderando que a bateria usada (PCF) foi normatizada para crianças que frequentavam escolas privadas. Questionamos, mais uma vez, se todas as habilidades fonêmicas testadas seriam, de fato, necessárias para aquela faixa etária.

Em outro estudo realizado por Freitas e Vidor (2005), com o objetivo de comparar o desempenho de adultos e crianças em diferentes habilidades fonológicas, foi utilizada a bateria do CONFIAS (MOOJEN et al., 2003), que é constituída por diferentes tarefas envolvendo sílabas e fonemas. A aplicação foi feita com crianças da $1^{\mathrm{a}}$ série e adultos que estavam no $1^{\circ}, 2^{\circ}$ e $3^{\circ}$ graus. Os resultados apontaram que o desempenho em tarefas envolvendo sílabas foi alto e semelhante entre todos os grupos, enquanto que, nas tarefas envolvendo fonemas, o desempenho também foi semelhante, mas baixo em todos os grupos. Ou seja, mesmo para os adultos com níveis de escolaridade mais alta, o desempenho numa tarefa que demandava segmentar palavras em fonemas não ultrapassou $28,6 \%$ de acertos, situação que, obviamente não impediu que eles tivessem se alfabetizado. É curioso constatar que, naquele estudo, os adultos com alta escolaridade demonstravam estranheza quando eram solicitados a pronunciar separadamente os fonemas de uma palavra.

No presente estudo, buscamos examinar alunos que estavam concluindo a alfabetização em turmas nas quais o método fônico era cuidadosamente aplicado pelas docentes. Tivemos, assim, como objetivo geral, verificar se, de fato, algumas habilidades (fonêmicas) continuariam sendo muito complexas mesmo para crianças que já teriam compreendido o princípio alfabético e podiam usar a maioria 
das convenções som-grafia do português. Como objetivos adicionais, buscamos: i) analisar qualitativamente as condutas não-verbais e as verbalizações expressas pelos aprendizes, enquanto resolviam tarefas de consciência fonêmica e ii) analisar as relações entre o rendimento em habilidades de consciência fonêmica e o desempenho revelado na leitura de palavras, de frases e de textos.

\section{METODOLOGIA}

Considerando nossos objetivos, a presente pesquisa apresentou caráter quase experimental. Descreveremos, a seguir, o processo de seleção das crianças participantes e as tarefas a elas aplicadas.

\section{CARACTERIZAÇÃO DOS SUJEITOS PARTICIPANTES}

Nossos sujeitos foram 20 crianças com hipótese alfabética de escrita, isto é, que já conseguiam ler e escrever palavras não memorizadas e que estavam concluindo o $1^{\circ}$ ano do ensino fundamental na rede pública de um município de Pernambuco, na qual o programa Alfa e Beto era usado em todas as escolas.

Após uma cuidadosa busca, localizamos alfabetizadoras que, de fato, aplicavam rigorosamente aquele método fônico, embora fizessem algumas poucas adaptações de certas atividades propostas ou acrescentassem outras de sua própria autoria. Nosso interesse era assegurar que as crianças tivessem sido expostas aos procedimentos do método fônico em questão, e constatamos que isso as docentes conseguiam cumprir, mesmo quando faziam as pequenas adaptações já citadas. Cabe ressaltar que acompanhamos e gravamos em áudio cinco jornadas completas de aulas, em cada turma, a fim de garantir que o método era cuidadosamente aplicado pelas professoras.

Considerando a dificuldade em localizar todos os sujeitos com o perfil que estabelecemos em uma mesma turma, fizemos a coleta em duas salas de aulas diferentes. ${ }^{1}$

$\mathrm{Na}$ escola 01, onde estavam localizadas 10 das crianças pesquisadas, o ensino envolvendo consciência fonêmica tomava $26 \%$ do tempo de ensino de alfabetização e o trabalho envolvendo o ensino de relações entre grafemas e fonemas ocupava 52\% do tempo dedicado ao àquele ensino.

$\mathrm{Na}$ escola 02, onde estavam localizadas as demais crianças participantes (10), nos dias em que observamos, a docente dedicou $22 \%$ do tempo a atividades de consciência fonêmica e $34 \%$ do 
tempo foi destinado ao ensino de relações entre grafemas e fonemas. Diferentemente da primeira turma, um percentual razoável de tempo era destinado a atividades de cópia (de palavras e frases). Em ambos os grupos-classe era reduzido o tempo dedicado à leitura e compreensão de textos, assim como à produção de textos escritos.

Considerando especificamente o ensino da apropriação do sistema de escrita alfabético, notamos nas duas turmas que, dentre as habilidades de consciência fonológica, aquelas priorizadas eram as de consciência fonêmica: identificação da posição do fonema pronunciado nas palavras orais, identificação de palavras orais que possuíamo(s) fonema(s) pronunciado(s), identificação do fonema inicial de palavras, identificação da letra (oralmente) a partir da escuta de fonema, produção de palavra (oral) que tivesse o fonema pronunciado no início, produção de sílaba (oralmente) a partir da escuta de fonemas, produção de palavras (oralmente) que tivessem o fonema pronunciado no meio, produção de palavras(oralmente) que tivessem o fonema pronunciado no final, produção de palavras (oralmente) a partir da escuta de todos os fonemas (síntese de fonemas), segmentação das palavras em fonemas e contagem de letras e fonemas a partir de uma palavra. Não identificamos atividades envolvendo sílabas ou rimas.

O apêndice 1 traz um exemplo das escritas produzidas por uma criança participante, indicando que suas notações revelavam uma hipótese alfabética já com boa convencionalidade no uso das letras, de modo que o que escrevia podia ser lido por um adulto que não tivesse presenciado a aplicação da tarefa de escrita de palavras.

Além da autorização da gestão da rede municipal onde as crianças estudavam, obtivemos o consentimento de seus pais para que integrassem a amostra da pesquisa.

\section{TAREFAS DE ESCRITA, DE CONSCIÊNCIA FONOLÓGICA E DE LEITURA APLICADAS}

Inicialmente, houve a aplicação de uma atividade individual de escrita de palavras com todas as crianças das turmas onde foram localizadas. Esta tarefa teve como objetivo selecionar sujeitos com hipótese de escrita alfabética, ou seja, que já tivessem compreendido o sistema de escrita alfabética e, ademais, que usassem letras com seus valores sonoros convencionais.

Em seguida, houve a aplicação de nove tarefas de consciência fonêmica, baseadas em Morais, A. (2004); Leite (2006); Moojen et al. (2003) e Aragão e Morais (2013). Ao final, foram aplicadas três tarefas de leitura: de palavras, de frases e de texto. 
O objetivo das tarefas de consciência fonêmica foi verificar em quais das habilidades testadas os sujeitos apresentavam melhor e pior desempenho. As tarefas foram as seguintes:

2.2.1. Identificação de palavras com o mesmo fonema inicial (IPFI). O adulto mostrava 4 figuras, dizia seus nomes e perguntava quais palavras começavam com o mesmo "sonzinho".

2.2.2. Identificação de palavras com o mesmo fonema final (IPFF): $\mathrm{O}$ adulto mostrava 4 figuras, dizia seus nomes e perguntava quais palavras terminavam com o mesmo "sonzinho".

2.2.3. Produção de palauras com mesmo fonema inicial (PPF): $\mathrm{O}$ adulto dizia uma palavra e pedia que o sujeito dissesse outra que começasse com o mesmo "sonzinho".

2.2.4. Segmentação de palavras em fonemas (SOFo): $\mathrm{O}$ adulto apresentava uma figura para a criança, dizia a palavra e solicitava que a segmentasse em "sonzinhos pequeninhos". Metade das palavras-exame continham dígrafos (por exemplo, chuva, guerra) e a outra metade não (bote, lwva), a fim de ver se as crianças estavam pensando sobre fonemas ou sobre letras.

2.2.5. Contagem de fonemas nas palavras (COF): $\mathrm{O}$ adulto pronunciava uma palavra para a criança e solicitava que ela fizesse a contagem dos "sonzinhos pequenininhos". Metade das palavras-exame continha dígrafos e a outra metade não.

2.2.6. Adição de fonemas em palavras reais (AFPR): $\mathrm{O}$ adulto pronunciava um fonema (por exemplo, /f/, em seguida uma palavra real (por exemplo, oca), e pedia para o sujeito adicionar ao início da palavra aquele "sonzinho" e dizer qual a nova palavra formada.

2.2.7. Produção de palavras a partir da escuta de fonemas iniciais (PPFA): $\mathrm{O}$ adulto pronunciava um fonema e solicitava que o sujeito dissesse uma palavra que começasse com o mesmo "sonzinho".

2.2.8. Subtração de fonema em palavras reais (SFPR): O adulto solicitava que o sujeito explicitasse a palavra real formada a partir da subtração de um fonema (Por exemplo, "se eu tirar o sonzinho /v/ da palavra vela, como fica?").

2.2.9. Sintese de fonemas (SOF): $\mathrm{O}$ adulto pronunciava a sequência de fonemas de uma determinada palavra e pedia que o sujeito os unisse e dissesse a palavra formada.

Em cada tarefa, o adulto apresentou dois exemplos e, em seguida, foram realizados dois itens de treino, para garantir que a criança pudesse melhor compreender o comando; por fim, eram 
realizados quatro itens de exame. Diante de respostas incorretas, durante os itens de treino, o adulto dava um feedback, dizendo o que escolheria ou o que diria, conforme a atividade apresentada. Esse procedimento foi adotado para contribuir com que o sujeito se familiarizasse com o que estava sendo solicitado. Nas tarefas que envolviam a identificação ou produção de palavras compartilhando determinado fonema, após cada resposta da criança lhe indagávamos: "como é que você descobriu?" ou "como você sabe que é X?". Todas as situações de aplicação foram gravadas, de modo a podermos analisar as condutas reveladas também nas demais tarefas (por exemplo, o que os sujeitos faziam e falavam, quando lhes pedíamos que contassem os fonemas de uma palavra ou que segmentassem um a um, em voz alta, os fonemas de outra palavra). ${ }^{2}$

As tarefas de leitura foram três. $\mathrm{O}$ adulto realizou a leitura dos comandos das questões e o aluno respondeu, lendo as alternativas e marcando apenas uma delas.

$\mathrm{Na}$ leitura de palavras utilizamos uma folha com seis desenhos (panela, mola, dragão, bandeira, perfume, escada). Ao lado de cada figura apresentávamos quatro alternativas de palavra, onde o sujeito era orientado a escolher e a marcar aquela que correspondesse ao nome do desenho. Distratores foram incluídos, de modo que além da palavra correta, duas outras começavam ou terminavam com grafia parecida.

Na leitura de frases, apresentamos três frases incompletas, cada uma possuía um quadrinho com uma cena que ajudava a completála, e quatro alternativas de palavras, para que os sujeitos lessem a frase e, com o auxílio dos quadrinhos, escolhessem a alternativa que a completasse corretamente.

$\mathrm{Na}$ leitura do texto, oferecemos um texto informativo seguido de três alternativas para que as crianças marcassem aquela que seria mais adequada como título do texto.

A fim de evitar cansaço ou desmotivação, a aplicação das diferentes tarefas ocorreu em três dias. Visando a reduzir efeitos de ordem, as habilidades de consciência fonêmica tiveram sua ordem de aplicação randomizada.

\section{RESULTADOS}

Os resultados do presente trabalho serão apresentados em duas partes. A primeira consiste na análise quantitativa, que traz o desempenho médio dos sujeitos nas diferentes tarefas de consciência fonêmica e naquelas de leitura, examinando como se relacionam. 
A segunda parte consiste na análise qualitativa dos erros e acertos observados nas respostas formuladas pelas crianças, ao responder cada uma das nove tarefas de consciência fonêmica.

ANÁLISE QUANTITATIVA: 0 DESEMPENHO MÉDIO NAS HABILIDADES DE CONSCIÊNCIA FONÊMICA

Ao examinar a facilidade ou dificuldade relativa das diferentes habilidades de consciência fonêmica, chegamos aos dados resumidos na Tabela 01, que mostra as médias absoluta e percentual de acertos, além dos desvios-padrão registrados em cada tarefa.

Constatamos que, apesar de terem sido treinados durante todo o ano em habilidades de consciência fonêmica, nossos aprendizes já com hipótese alfabética de escrita só tiveram êxito superior a 80\% em uma das tarefas e que em quatro delas seus índices médios de acertos foram inferiores a $50 \%$.

TABELA 1. Desempenho das crianças nas diferentes tarefas de consciência fonêmica

\begin{tabular}{|l|c|c|}
\hline \multicolumn{1}{|c|}{ Tarefa } & $\begin{array}{c}\text { Médias de acertos } \\
\text { das crianças } \\
\text { Absoluta (Percentual) }\end{array}$ & $\begin{array}{c}\text { Desvio } \\
\text { padrão }\end{array}$ \\
\hline Identificação de palavras com o mesmo fonema inicial (IPFI) & $3,45(86,25 \%)$ & 0,94 \\
\hline Contagem de fonemas nas palavras (COF) & $3,15(78,75 \%)$ & 1,34 \\
\hline Identificação de palavras com o mesmo fonema final (IPFF) & $2,85(71,25 \%)$ & 1,08 \\
\hline Produção de palavras a partir da escuta de fonema iniciais (PPFA) & $2,75(68,75 \%)$ & 1,11 \\
\hline Adição de fonemas em início de palavras reais (AFPR) & $2,4(60 \%)$ & 1,39 \\
\hline Síntese de fonemas (SOF) & $1,95(48,75 \%)$ & 0.99 \\
\hline Produção de palavras com o mesmo fonema inicial (PPF) & $1,9(47,5 \%)$ & 1,33 \\
\hline Subtração de fonema em palavras reais (SFPR): & $1,9(47,5 \%)$ & 1,33 \\
\hline Segmentação das palavras em fonemas (SOFo) & $0,7(17,5 \%)$ & 0,92 \\
\hline
\end{tabular}

Fonte: Dados da pesquisa.

Obs.: $N$ máximo das médias absolutas de acertos $=4$.

Verificamos que na tarefa de Identificação de palavras com o mesmo fonema inicial (IPFI) apresentaram um desempenho superior 
ao revelado nas demais tarefas, o que confirma o já constatado em algumas pesquisas prévias feitas com crianças brasileiras em alfabetização (MORAIS, A. G. 2004, 2015; LEITE 2011; ARAGÃO; MORAIS, A. G. 2013). Na tarefa de Contagem defonemas, diferentemente do encontrado pelos estudos agora citados, nossos sujeitos tiveram um bom desempenho $(78,75 \%)$ de acertos. Não foram encontradas diferenças entre a contagem de fonemas em palavras com dígrafos e aquelas que não os continham, mas veremos, em nossas análises qualitativas, que as crianças em mais de $70 \%$ dos casos de acertos pronunciavam os nomes de letras.

Vimos, também que em duas tarefas: Identificação de palavras com o mesmo fonema final (IPFF) e Produção de palaura a partir da escuta de fonemas (PPFA), a média de acertos daquelas crianças ficou em torno de $70 \%$. Já na Adição de fonemas em início de palavras reais (AFPR) a média de acertos baixou para $60 \%$. Porém, quando apresentarmos com mais detalhes as análises qualitativas, verificaremos que, apesar da presença de um ensino sistemático da pronúncia de fonemas, nas salas de aula de nossos sujeitos, seus acertos estiveram relacionados predominantemente à pronúncia, em voz alta, das letras das palavras em foco.

Observamos, ademais, que o desempenho das crianças, nas tarefas de Sintese de fonemas (SOF) e na Subtração de fonema em palauras reais (SFPR), revelou médias de acertos um pouco inferiores a 50\%. Já na Segmentação das palavras em fonemas (SOFo), seu desempenho médio foi inferior a $20 \%$ !

Ressaltamos, assim, o quanto em metade das tarefas de consciência fonêmica aplicadas, os alfabetizandos permaneceram com acertos médios oscilando entre $17,5 \%$ e apenas $60 \%$, mesmo sendo meninos e meninas que estavam inseridos em turmas onde o método fônico, adotado por sua rede pública de ensino, era cuidadosamente aplicado.

\section{OS RESULTADOS NAS TAREFAS DE LEITURA E A ASSOCIAC̣ÃO ENTRE HABILIDADES DE CONSCIÊNCIA FONÊMICA E DE LEITURA}

A proporção média de acertos das crianças nas tarefas de leitura, ao final do $1^{\circ}$ ano do ensino fundamental, é apresentada na Tabela 02.

TABELA 2. Média percentual de acertos nas tarefas de leitura

\begin{tabular}{|c|c|c|c|}
\hline & \multicolumn{3}{|c|}{ Leitura } \\
\hline & Palavras & Frases & Texto \\
\hline Média & 0,93 & 0,42 & 0,25 \\
\hline Desvio-padrão & 0,09 & 0,32 & 0,44 \\
\hline
\end{tabular}

Fonte: Dados da pesquisa. 
A proporção média de acertos das crianças nas tarefas de leitura mostra que, ao final do $1^{\circ}$ ano letivo, elas revelavam facilidade na leitura de palavras. No entanto, as tarefas que envolviam a leitura de frases e do texto foram, ainda, de difícil realização para os aprendizes. Destas, foi na tarefa de leitura de texto que as crianças apresentaram mais dificuldade: somente $25 \%$ delas conseguiram identificar o tema do texto lido. É interessante também observar que, tal como indicado pelos desviospadrão, as variações de desempenho entre os sujeitos pesquisados foram muito maiores nas tarefas de leitura de frases e de texto.

Os dados indicam que a habilidade de ler palavras encontravase mais próxima ao processo de apropriação do sistema de escrita vivenciado com o método fônico em suas salas de aula. Por outro lado, o mediano e o baixo desempenho, respectivamente, na leitura de frases e de texto, indicam que as crianças não se encontravam "alfabetizadas", se considerarmos os critérios formulados tanto por Soares (2016), como pelo MEC (BRASIL, 2012), quando este último definiu os direitos de aprendizagem das crianças para os três primeiros anos do ciclo de alfabetização.

A fim de examinar a associação entre as habilidades de consciência fonêmica e a leitura, são apresentados, na Tabela 03, os coeficientes de correlação parcial entre cada uma das habilidades de consciência fonêmica e as três tarefas de leitura.

TABELA 3. Coeficientes de Correlação Parcial entre as tarefas de consciência fonêmica e de leitura

\begin{tabular}{|l|c|c|c|}
\hline & \multicolumn{3}{|c|}{ Leitura } \\
\hline & Palavras & Frases & Texto \\
\hline Identificação de palavras com o mesmo fonema inicial (IPFI) & $0,62^{* *}$ & $0,50^{*}$ & $-0,28$ \\
\hline Produção de palavras com o mesmo fonema inicial (PPF) & 0,02 & 0,24 & 0,02 \\
\hline Segmentação das palavras em fonemas (SOFo) & 0,07 & 0,32 & $-0,26$ \\
\hline Contagem de fonemas nas palavras (COF) & $0,51^{*}$ & 0,20 & 0,19 \\
\hline Identificação de palavras com o mesmo fonema final (IPFF) & $-0,12$ & 0,35 & 0,42 \\
\hline Produção de palavras a partir da escuta de fonema iniciais (PPFA) & 0,00 & $0,53^{*}$ & 0,09 \\
\hline Subtração de fonema em palavras reais (SFPR) & 0,42 & 0,21 & $-0,14$ \\
\hline Síntese de fonemas (SOF) & 0,17 & 0,19 & $-0,11$ \\
\hline Adição de fonemas em início de palavras reais (AFPR) & $-0,08$ & 0,09 & $0,52^{*}$ \\
\hline
\end{tabular}

Fonte: Dados da pesquisa.

Nota: ${ }^{*} \mathrm{p}<.05 ;{ }^{*} \mathrm{p}<.01$ (FONTE: nossos dados) 
Observou-se que a habilidade de Identificação de palavras com o mesmo fonema inicial (IPFI) se correlacionou de forma significativa com as tarefas de leitura de palavras e frases. A Contagem de fonemas nas palauras (COF) se associou de forma significativa com a leitura de palavras, enquanto a Produção de palavras a partir da escuta de fonema iniciais (PPFA) se correlacionou significativamente com a leitura de frases.

Os resultados apresentados nessa seção dialogam com os que Maluf e Puliezi (2012) encontraram, considerando que a Identificação de palavras com o mesmo fonema inicial (IPFI) também apresentou correlação com a habilidade de ler palavras. Porém, cabe ressaltar que foram poucas habilidades que atingiram a significância e que um número ainda menor daquelas habilidades estaria relacionado com uma capacidade de compreender unidades linguísticas como frases ou textos.

\section{ANÁLISE QUALITATIVA}

Nesta etapa do trabalho, procuramos analisar as respostas e justificativas apresentadas pelos sujeitos nas diferentes tarefas de consciência fonêmica. Trataremos das tarefas, considerando a ordem decrescente dos percentuais médios de acertos encontrados.

\section{ANÁLISE QUALITATIVA DO DESEMPENHO NA ATIVIDADE DE IDENTIFICAÇÃO DE PALAVRAS COM O MESMO FONEMA INICIAL (IPFI)}

O quadro 01 apresenta os diferentes tipos de justificativas dados pelas crianças na resolução da tarefa de Identificação de palavras com o mesmo fonema inicial (IPFI). 
QUADRO 1. Tipos de justificativas dadas pelas crianças na tarefa de Identificação de palavras com o mesmo fonema inicial (IPFI)

\begin{tabular}{|c|c|c|c|c|c|c|c|}
\hline & Acerto / Erro & $\begin{array}{c}\text { Não justifica } \\
\text { ou diz apenas } \\
\text { “porque é". } \\
\text { justificativa } \\
\text { que não } \\
\text { demonstra } \\
\text { reflexão } \\
\text { fonológica. }\end{array}$ & $\begin{array}{c}\text { Diz que } \\
\text { começa com } \\
\text { o mesmo som } \\
\text { ou a mesma } \\
\text { letra (sem } \\
\text { verbalizar) }\end{array}$ & $\begin{array}{c}\text { Fala a } \\
\text { Letra inicial }\end{array}$ & $\begin{array}{c}\text { Pronuncia } \\
\text { ofonema } \\
\text { inicial }\end{array}$ & $\begin{array}{c}\text { Imita a } \\
\text { pronúncia } \\
\text { dos } \\
\text { fonemas }\end{array}$ & Total \\
\hline Acerto & 8 & 6 & 8 & 34 & 9 & 4 & 69 \\
\hline Erro & 6 & 3 & 1 & 0 & 0 & 1 & 11 \\
\hline Justificativas & 14 & 9 & 9 & 34 & 9 & 5 & 80 \\
\hline
\end{tabular}

Fonte: Dados da pesquisa.

$\mathrm{Na}$ presente tarefa, encontramos o melhor desempenho entre os sujeitos (86,25\% de acertos). No entanto, ao analisar as justificativas dos acertos, verificamos que prevaleceu a verbalização da letra inicial, como se pode ver no exemplo a seguir:

P*- Então, aqui eu tenho: siri, mala, moto e chave... Qual começa com o mesmo sonzinho que mala?

A.109**- moto

P. Por que você escolheu moto?

A.109- Porque tem um $M$ igual à mala.

P. Muito bem! Aqui eu tenho pia, rato, bola e roda...Qual começa com o mesmo sonzinho que roda?

A.109- rato

P. Muito bem! Por quê?

A.109- Porque tem R.

\footnotetext{
* Pesquisadora

${ }^{* *}$ Aluno
}

Além disso, se considerarmos o total de justificativas, identificamos que em torno de $77 \%$ das respostas certas, os alunos conseguiram realizar reflexão fonológica, sem necessariamente pronunciar os fonemas.

Se a pronúncia do fonema inicial isolado só ocorreu em 11\% das respostas, verificamos, também, que, em alguns casos (em torno de $6 \%$ ) os alunos exerceram um enorme esforço para pronunciar em 
voz alta os fonemas iniciais, mas não conseguiam fazê-lo. Vejamos a seguinte situação:

OP- Veja bem: siri, mala, moto e chave... Qual começa com o mesmo sonzinho que mala?

A.102- (Demora para responder) Moto

P. Muito bem! Por que você escolheu moto?

A.102- Porque eu ouvi o som uhhh! (tenta imitar $/ \mathrm{m} /$ )

P. Ok! Aqui eu tenho pia, rato, bola e roda... Qual começa com o mesmo sonzinho que roda?

A.102- bola

P. OK! Por quê?

A.102- Porque eu ouvi o som [bu] [bu] [bu]! (tenta imitar /b/)

* Pesquisadora

${ }^{*}$ Aluno

Acreditamos que o aluno 102 tentou imitara pesquisadora (a partir do que escutou nos itens de exemplo) e a docente da turma (considerando a prática de ensino vivenciada, já que sua professora procurava enfatizar a pronúncia dos fonemas com frequência).

Quanto aos erros, constatamos que foram poucos e que, em suas justificativas, os alunos, de forma geral, não verbalizaram qualquer segmento.

ANÁLISE QUALITATIVA DO DESEMPENHO NA TAREFA DE CONTAGEM DE FONEMAS NAS PALAVRAS (COF)

Nesta tarefa, as crianças apresentaram um desempenho bom ( $78,25 \%$ de acertos). O quadro 02 abaixo apresenta o que encontramos como condutas espontâneas. 
QUADRO 2. Condutas concomitantes aos acertos na tarefa de Contagem de fonemas nas palavras (COF)

\begin{tabular}{|c|c|c|c|c|c|c|}
\hline Ações & Diz nada & $\begin{array}{c}\text { Diz as letras } \\
\text { das palavras }\end{array}$ & $\begin{array}{c}\text { Pronuncia } \\
\text { letras e } \\
\text { fonemas }\end{array}$ & $\begin{array}{c}\text { Pronuncia } \\
\text { letras e } \\
\text { sílabas }\end{array}$ & $\begin{array}{c}\text { Imita a } \\
\text { pronúncia } \\
\text { dos fonemas } \\
\text { e pronuncia } \\
\text { algumas letras }\end{array}$ & TOTAL \\
\hline Quantidade & 18 & 6 & 13 & 6 & 21 & 64 \\
\hline
\end{tabular}

Fonte: Dados da pesquisa.

A resposta que prevaleceu foi a imitação da pronúncia dos fonemas e a pronúncia de algumas letras. Houve destaque também para respostas onde os alunos não realizavam a pronúncia de qualquer segmento. Essas duas condutas podem ser observadas nos exemplos abaixo:

P- Quantos sonzinhos tem a palavra lua.

A.107- [1ã] U A (pegou três cubos).

(...)

P- E a palavras queda?

A.107- Q E [dã] A quatro (Pegou quatro cubos).

P- Quantos sonzinhos tem a palavra lua?

A.109- três (P. pegou três cubos).

P- Muito bem! E quantos sonzinhos tem a palavra bola.

A.109- quatro (P. Pegou quatro cubos sem pronunciar nada da palavra).

\section{* Pesquisadora}

${ }^{* *}$ Aluno

Os dados expostos indicam que os alunos, em sua maioria, apesar de acertarem a quantidade de fonemas, não pareceram pensar nos mesmos como unidades sonoras isoladas. Ao invés disso, eles acabaram recorrendo, tal como veremos na tarefa de segmentação de palavras em fonemas (SOFo), a diferentes outros segmentos (letras, sílabas) e à tentativa malsucedida de pronúncia de fonemas. 
ANÁLISE QUALITATIVA DO DESEMPENHO NA TAREFA DE IDENTIFICAÇÃO DOS FONEMAS FINAIS NAS PALAVRAS (IPFF)

O quadro 03, abaixo, apresenta os tipos de justificativas dadas pelos alunos, quando eram solicitados a identificar os fonemas finais nas palavras.

QUADRO 3. Tipos de justificativas dadas pelas crianças na tarefa de Identificação de palauras com o mesmo fonema final (IPFF)

\begin{tabular}{|c|c|c|c|c|c|c|c|}
\hline Justificativas & $\begin{array}{c}\text { Não justifica } \\
\text { ou diz apenas } \\
\text { "porque é". }\end{array}$ & $\begin{array}{c}\text { Dá } \\
\text { justificativa } \\
\text { que não } \\
\text { demonstra } \\
\text { reflexão } \\
\text { fonológica. }\end{array}$ & $\begin{array}{c}\text { “Termina } \\
\text { igual, termina } \\
\text { com o mesmo } \\
\text { som ou } \\
\text { pedacinho ou } \\
\text { letra" (sem } \\
\text { verbalizar) }\end{array}$ & $\begin{array}{c}\text { Fala a } \\
\text { silaba final }\end{array}$ & $\begin{array}{c}\text { Fala a letra } \\
\text { final }\end{array}$ & $\begin{array}{c}\text { Pronuncia } \\
\text { ofonema } \\
\text { final }\end{array}$ & $\begin{array}{c}\text { Total } \\
\text { acertos e } \\
\text { erros }\end{array}$ \\
\hline Acerto & 4 & 6 & 16 & 1 & 32 & 1 & 60 \\
\hline Erro & 7 & 1 & 8 & 0 & 4 & 0 & 20 \\
\hline $\begin{array}{c}\text { TOTAL } \\
\text { RESPOSTAS }\end{array}$ & 11 & 7 & 24 & 1 & 36 & 1 & 80 \\
\hline
\end{tabular}

Fonte: Dados da pesquisa.

Verificamos que os sujeitos apresentaram um "bom" desempenho nesta tarefa $(71,5 \%)$, porém, quando analisamos as justificativas apresentadas, constatamos que prevaleceu, mais uma vez, a pronúncia das letras no final das palavras, seguida das justificativas da categoria "termina igual, termina com o mesmo som ou pedacinho ou letra etc.", sem, no entanto, explicitar verbalmente o fonema. Podemos ilustrar esse modo de funcionamento com o exemplo abaixo:

P- Qual desses (apontando para os demais desenhos) termina com o mesmo sonzinho que "cupim" (mostra a figura do cupim)
A.113-jardim
P- Por quê?

A.113- Porque tem a mesma letra.

P- Qual desses (apontando para os demais desenhos) termina com o mesmo sonzinho que cola? (mostra a figura da cola)
A.113- luva
P- Por quê?
A.113- Porque tem o mesmo som, a mesma letra é igual.

\footnotetext{
* Pesquisadora

** Aluno
} 
Ressaltamos que, nesta tarefa, assim como em outras anteriores, não havia qualquer distinção entre a pronúncia das letras e dos fonemas dos sons vocálicos e os alunos pareciam muito tranquilos em pronunciar letras.

ANÁLISE QUALITATIVA DO DESEMPENHO NA TAREFA DE PRODUÇ̃̃o DE PALAVRAS A PARTIR DA ESCUTA DE FONEMAS INICIAIS (PPFA)

Constatamos que houve um razoável índice de acertos nesta tarefa $(68,75 \%)$.

O quadro 04, abaixo, apresenta os tipos de erros cometidos, quando solicitamos que os alunos produzissem uma palavra com determinado fonema pronunciado pelo adulto.

QUADRO 4. Tipos de erros cometidos pelas crianças na tarefa de Produção de palavras a partir da escuta de fonema iniciais (PPFA)

\begin{tabular}{|c|c|c|c|c|c|}
\hline Respostas & Não responde & $\begin{array}{c}\text { Não apresenta } \\
\text { resposta que } \\
\text { indique reflexão } \\
\text { fonológica }\end{array}$ & $\begin{array}{c}\text { Troca 0s } \\
\text { fonemas }\end{array}$ & $\begin{array}{c}\text { Produz palavras que } \\
\text { não existem, mas que } \\
\text { possuem o fonema } \\
\text { inicial solicitado. }\end{array}$ & Total \\
\hline $\begin{array}{c}\text { Quantidade } \\
\text { respostas }\end{array}$ & 3 & 4 & 12 & 6 & 25 \\
\hline
\end{tabular}

Fonte: Dados da pesquisa.

Ao analisar o que os alunos diziam, quando erravam, vimos que esteve mais presente, entre os erros, a troca de fonemas, como ocorreu no exemplo abaixo:

P- Agora você vai me dizer uma palavra que começa com o sonzinho / $/$ /

A.114- sapo

P- E agora você vai me dizer uma palavra que começa com o sonzinho /s/

A.114- casa

(...)

Como podemos observar a criança ao invés de produzir uma palavra iniciada com o fonema $/ \mathrm{J} /$ produziu sapo, que começa com o fonema / s/e, quando solicitada a produzir uma palavra com o fonema /s, produziu casa que começa com o fonema / $\mathrm{k} /$. Esses tipos de erros também foram encontrados por Aragão e Morais (2013). 
ANÁLISE QUALITATIVA DO DESEMPENHO NA TAREFA DE ADIÇ̃̃O DE FONEMAS EM INÍCIO DE PALAVRAS REAIS (AFPR)

Nesta tarefa, os alunos tiveram um percentual de acertos de apenas $60 \%$. O quadro 05, abaixo, apresenta os tipos de erros revelados pelos sujeitos, quando solicitados a adicionarem um fonema a determinada palavra:

QUADRO 5. Tipos de erros cometidos pelas crianças na tarefa de Adição de fonemas em início de palavras reais (AFPR)

\begin{tabular}{|c|c|c|c|}
\hline Respostas & $\begin{array}{c}\text { Adiciona um (ns) fonema(s) } \\
\text { diferente(s) no ińcio da palavra } \\
\text { apresentada }\end{array}$ & $\begin{array}{c}\text { Produz outra palavra com 0 } \\
\text { fonema pronunciado }\end{array}$ & Total \\
\hline Total & 12 & 20 & 32 \\
\hline
\end{tabular}

Fonte: Dados da pesquisa.

O tipo de erro que prevaleceu foi a produção de outra palavra com o fonema pronunciado. O exemplo abaixo ilustra essa forma de responder:

P*-Se eu colocar o sonzinho /1/ no começo da palavra wva qual palavra forma?

A.119**-luta

P- E se eu colocar o sonzinho /K/ no começo da palavra ano, qual palavra forma?

A.119- Kane

\section{* Pesquisadora}

** Aluno

O exemplo mostra que o aluno, apesar de errar, apresentou respostas que mostraram reflexão fonológica. Os tipos de erros identificados nesta tarefa, também foram constatados por Aragão e Morais (2013). A dificuldade pareceu estar relacionada ao nível de esforço cognitivo exigido pela tarefa, já que a criança precisava pensar, simultaneamente, em cada unidade pronunciada (fonema e palavra) e, em seguida, realizar mentalmente a junção entre aquelas "partes", considerando, inclusive, a ordem, já que o fonema não podia ser colocado em qualquer posição da palavra, mas no início. 


\section{ANÁLISE QUALITATIVA DO DESEMPENHO NA SÍNTESE DE FONEMAS (SOF)}

Nesta tarefa, o percentual de acertos foi ainda mais baixo $(48,75 \%)$. O quadro 06 apresenta os tipos de erros cometidos pelos sujeitos, quando solicitados a realizar a síntese de fonemas escutados, de modo a formar palavras:

QUADRO 6. Tipos de erros revelados na Síntese de fonemas (SOF)

\begin{tabular}{|c|c|c|c|c|}
\hline $\begin{array}{c}\text { Tipos de } \\
\text { erros }\end{array}$ & $\begin{array}{c}\text { Produz outra palavra } \\
\text { com o primeiro fonema } \\
\text { solicitado }\end{array}$ & $\begin{array}{c}\text { Não demonstra } \\
\text { reflexão } \\
\text { fonológica }\end{array}$ & $\begin{array}{c}\text { Produz palavra com os } \\
\text { fonemas pronunciados, mas } \\
\text { muda a ordem considerando } \\
\text { a pronúncia e/ou adiciona } \\
\text { outros fonemas. }\end{array}$ & Total \\
\hline Total & 28 & 1 & 12 & 41 \\
\hline
\end{tabular}

Fonte: Dados da pesquisa.

Constatamos que prevaleceu a produção de outra palavra com o primeiro fonema solicitado, tal como no exemplo abaixo:

P*- Qual palavra é formada pelos sonzinhos $/ \mathrm{J} / \mathrm{a} /$ ?

A*-116 china

* Pesquisadora

** Aluno

ANÁLISE QUALITATIVA DO DESEMPENHO NA TAREFA PRODUC̣ÃO DE PALAVRAS COM 0 MESMO FONEMA INICIAL (PPF)

O quadro 07 apresenta os diferentes tipos de justificativas dados pelas crianças na resolução da tarefa de Produção de palauras com o mesmo fonema inicial (PPF). 
QUADRO 7. Tipos de justificativas dadas pelas crianças na tarefa de Produção de palavras com o mesmo fonema inicial (PPF)

\begin{tabular}{|c|c|c|c|c|c|c|c|c|c|}
\hline Escolas & $\begin{array}{c}\text { Acertos/ } \\
\text { Erros }\end{array}$ & $\begin{array}{c}\text { Não } \\
\text { justifica } \\
\text { ou diz } \\
\text { apenas } \\
\text { "porque } \\
\text { é". }\end{array}$ & $\begin{array}{c}\text { Dá } \\
\text { justificativa } \\
\text { que não } \\
\text { demonstra } \\
\text { reflexão } \\
\text { fonológica. }\end{array}$ & $\begin{array}{c}\text { Diz que } \\
\text { começa } \\
\text { igual, } \\
\text { começa com } \\
\text { o mesmo } \\
\text { som ou } \\
\text { pedacinho, } \\
\text { ou letra } \\
\text { (sem } \\
\text { verbalizar o } \\
\text { segmento } \\
\text { sonoro) }\end{array}$ & $\begin{array}{l}\text { Fala a } \\
\text { sílaba } \\
\text { inicial. }\end{array}$ & $\begin{array}{c}\text { Fala a } \\
\text { letra } \\
\text { inicial. }\end{array}$ & $\begin{array}{c}\text { Imita a } \\
\text { pronúncia } \\
\text { dos } \\
\text { fonemas }\end{array}$ & $\begin{array}{c}\text { Pronuncia } \\
\text { o fonema } \\
\text { inicial }\end{array}$ & Total \\
\hline \multirow{2}{*}{ Total } & Acerto & 3 & 2 & 9 & 3 & 19 & 0 & 2 & 38 \\
\hline & Erro & 7 & 3 & 16 & 1 & 10 & 1 & 4 & 42 \\
\hline $\begin{array}{c}\text { Total } \\
\text { respostas }\end{array}$ & & 10 & 5 & 25 & 4 & 29 & 1 & 6 & 80 \\
\hline
\end{tabular}

Fonte: Dados da pesquisa.

Nesta tarefa, verificamos um desempenho semelhante ao registrado na tarefa anterior (47,5 \% de acertos médios). Em relação às justificativas, identificamos, mais uma vez, que, entre os acertos, prevaleceu a verbalização da letra inicial. Eis um exemplo:

P*-Agora você vai dizer uma palavra que começa com o mesmo sonzinho que coco.
A.111**: cocada
P. Por quê?

A.- 111. Porque começa com C.

P- Muito bem! E com a palavra jacare?

A.111- gelo
P. Por quê?

A.111- Porque começa com J.

* Pesquisadora

** Aluno

Nos casos de acertos, vemos que os alunos conseguiram resolver mesmo sem pronunciar os fonemas iniciais das palavras. Um exemplo chamou, particularmente, a nossa atenção: 
P- Qual é uma palavra que começa com o mesmo sonzinho que coco?

Aluno 106: cadeira

P. Por quê?

A.106- Porque tem o som do $\mathrm{C}$, nem me lembro, porque é muito difícil esse som, nem me lembro!

\section{* Pesquisadora \\ ** Aluno}

Os exemplos mostram que a criança sabia o que estava sendo solicitado, mas não tinha condições de pronunciar os fonemas iniciais ao atender à demanda.

Verificamos ademais que, nesta tarefa, apesar de serem solicitados a elaborar a reflexão sobre o fonema inicial, houve uma queda considerável no rendimento dos alunos. Sendo assim, diante da distinção apresentada, identificamos a necessidade de verificar quais tipos de erros esses alunos cometeram e, para isso, organizamos o quadro 08:

QUADRO 8. Tipos de erros na tarefa de Produção de palavras com o mesmo fonema inicial (PPF)

\begin{tabular}{|c|c|c|}
\hline Condutas & $\begin{array}{c}\text { Diz palavra iniciada } \\
\text { com um fonema } \\
\text { diferente do solicitado }\end{array}$ & $\begin{array}{c}\text { Diz palavra iniciada com } \\
\text { toda a sílaba inicial igual }\end{array}$ \\
\hline $\begin{array}{c}\text { Quantidade de } \\
\text { respostas }\end{array}$ & 02 & 40 \\
\hline
\end{tabular}

Fonte: Dados da pesquisa.

A análise revela que os alunos realizaram reflexão fonológica, mas, ao invés de produzirem palavras considerando apenas o fonema inicial, eles recordaram palavras considerando toda a sílaba inicial. Ressaltamos que, nesta tarefa, sempre que isso ocorria, enfatizávamos que queríamos apenas palavras com o mesmo "sonzinho inicial" e, para tanto, oferecemos exemplos e feedback, nos itens de treino e de exame, para ajudar as crianças a compreenderem o que estava sendo solicitado.

Tais dificuldades também foram identificadas nas pesquisas de diferentes autores (MORAIS, 2004, 2015; PESSOA, 2007; LEITE, 2011; AZEVEDO, 2011; ARAGÃO, MORAIS, 2013), e indicam que para os alunos é mais fácil evocar palavras refletindo sobre toda a sílaba inicial igual em lugar de fazê-lo isolando apenas o primeiro fonema. 

PALAVRAS REAIS (SFPR)

O quadro 09, abaixo, apresenta os tipos de erros cometidos pelos sujeitos, quando solicitados a subtrair um fonema e dizer a palavra formada.

QUADRO 9. Tipos de erros cometidos pelas crianças na tarefa de Subtração de fonema em palavras reais (SFPR)

\begin{tabular}{|c|c|c|c|c|c|c|c|}
\hline Respostas & $\begin{array}{c}\text { Não } \\
\text { demonstra } \\
\text { reflexão } \\
\text { fonológica }\end{array}$ & $\begin{array}{c}\text { Subtrai a } \\
\text { sílaba inicial }\end{array}$ & $\begin{array}{c}\text { Produz outra } \\
\text { palavra } \\
\text { com alguns } \\
\text { fonemas } \\
\text { do interior } \\
\text { da palavra } \\
\text { original }\end{array}$ & $\begin{array}{c}\text { Troca } \\
\text { apenas 0 } \\
\text { fonema } \\
\text { inicial por } \\
\text { outro }\end{array}$ & $\begin{array}{c}\text { Produz outra } \\
\text { palavra } \\
\text { apenas com a } \\
\text { sílaba inicial } \\
\text { da palavra } \\
\text { apresentada. }\end{array}$ & $\begin{array}{c}\text { Produz outra } \\
\text { palavra } \\
\text { apenas com 0 } \\
\text { fonema inicial } \\
\text { da palavra } \\
\text { apresentada }\end{array}$ & Total \\
\hline Total & 2 & 2 & 18 & 5 & 5 & 10 & 42 \\
\hline
\end{tabular}

Fonte: Dados da pesquisa.

Lembramos que os alunos apresentaram o mesmo percentual de acertos que na tarefa anterior $(47,5 \%)$. Sobre os tipos de erros cometidos, a tendência foi os sujeitos produzirem outra palavra com alguns fonemas da palavra original, tal como se constata no exemplo a seguir:

P*- Se eu tirar o sonzinho $/ \mathrm{m} /$ da palavra molho, qual palavra forma?

A.108**-óleo

P- E se eu tirar o sonzinho $/ \mathrm{k} /$ da palavra cama, qual palavra forma?

A.108- canga

\footnotetext{
* Pesquisadora

** Aluno
}

No presente estudo, os tipos de erros cometidos divergem daqueles encontrados por Aragão e Morais (2013), quando empregaram a mesma tarefa com crianças também alfabetizadas pelo método fônico. Esses autores identificaram que os sujeitos, ao errarem, em sua maioria, não apresentavam respostas que demonstrassem reflexão fonológica. No entanto, seus dados convergem com os que agora estamos analisando, quanto ao fato de que, em ambas as pesquisas, os grupos de crianças apresentaram desempenho inferior a $50 \%$ na tarefa em foco. Tal situação pode estar relacionada à demanda cognitiva implicada na Subtração de fonema em palavras reais 
(SFPR), pois era necessário localizar o primeiro fonema pronunciado na palavra, "extraí-lo" ao mesmo tempo e, mentalmente, deduzir a palavra resultante.

\section{ANÁLISE QUALITATIVA DO DESEMPENHO NA ATIVIDADE DE SEGMENTAÇÃO DAS PALAVRAS EM FONEMAS (SOFO)}

Recordemos que, nesta tarefa, o desempenho dos sujeitos foi o mais baixo: apenas $17,5 \%$ de acertos. Tal situação pode estar relacionada ao fato de que esta foi a única tarefa onde solicitamos aos nossos sujeitos que pronunciassem todos os fonemas das palavras e que o fizessem de modo sequenciado. Assim, não eram contabilizados acertos, se as crianças pensassem nas letras das palavras ou em suas sílabas. O quadro 10 apresenta a distribuição de tipos de erros revelados pelos alunos, quando pedimos que pronunciassem um a um os fonemas de quatro palavras.

QUADRO 10. Tipos de erros encontrados na tarefa de Segmentação das palavras em fonemas ( $\left.\mathrm{SOF}_{0}\right)$

\begin{tabular}{|c|c|c|c|c|c|c|c|c|}
\hline Justificativas & $\begin{array}{c}\text { Separa } \\
\text { em letras }\end{array}$ & $\begin{array}{c}\text { Separa } \\
\text { em letras } \\
\text { e fonemas }\end{array}$ & $\begin{array}{c}\text { Separa } \\
\text { em letras } \\
\text { e sílabas }\end{array}$ & $\begin{array}{c}\text { Separa } \\
\text { em } \\
\text { sílabas }\end{array}$ & $\begin{array}{c}\text { Separa } \\
\text { em } \\
\text { silabas e } \\
\text { fonemas }\end{array}$ & $\begin{array}{c}\text { Separa } \\
\text { em sílaba, } \\
\text { letra e } \\
\text { imita } \\
\text { fonemas }\end{array}$ & $\begin{array}{c}\text { Separa } \\
\text { em } \\
\text { fonema } \\
\text { e imita } \\
\text { fonemas }\end{array}$ & TOTAL \\
\hline $\begin{array}{c}\text { Quantidade } \\
\text { respostas }\end{array}$ & 9 & 10 & 7 & 14 & 5 & 12 & 9 & 66 \\
\hline
\end{tabular}

Fonte: Dados da pesquisa.

Lá observamos que a resposta que prevaleceu foi a separação de palavras em sílabas:

P*- Quais são os sonzinhos da palavra guerra?

A.116- [ge] [Ra]

P- E quais são os sonzinhos da palavra chave?

A-116- [xa] [vi]

P- E quais são os sonzinhos da palavra vela?

A-116- [ve] [la]

P- Agora você vai dizer os sonzinhos da palavra roda.

A. $116-[\mathrm{ro}][\mathrm{da}]$

* Pesquisadora

${ }^{* *}$ Aluno

Educação em Revista | Belo Horizonte | Dossiê Alfabetização e Letramento no Campo Educacional| v.36 | e223345 | 2020 
Além disso, identificamos que os demais erros estiveram distribuídos pelo uso de diferentes segmentos das palavras, de modo uniforme ou misturando-os, como ilustram os exemplos abaixo:

\section{Escola 1:}

$\mathrm{P}^{*}$ - E quais são os sonzinhos da palavra guerra.

A.102**- $[\mathrm{ge}] / \mathrm{R} /[\mathrm{ra}]$

P- E quais são os sonzinhos da palavra roda.

A.107- [ro] R O [d i i] A

P- E quais são os sonzinhos da palavra guerra.

A.104- [ge] /R/ / R/ / a/

\section{* Pesquisadora}

** Aluno

Nesses casos, nos chamou a atenção a variedade de segmentos pronunciados em uma mesma palavra para tentar dar conta da tarefa. Percebemos, assim, que os sujeitos pareciam compreender e tentar realizar o que estava sendo solicitado, porém, mesmo diante do ensino explícito dos fonemas isolados, que tinham vivenciado em sala de aula, houve bastante dificuldade.

\section{CONCLUSÕES OU... AINDA HÁ MUITO O QUE DEBATER SOBRE AS RELAÇ̃̃ES ENTRE CONSCIÊNCIA FONÊMICA E APRENDIZADO DA NOTAÇ̃̃O ALFABÉTICA}

Nossas análises atestaram que mesmo crianças ensinadas com um método fônico tiveram dificuldade em responder a diversas tarefas de consciência fonêmica que psicólogos e autores de livros didáticos vêm tratando como requisitos para a apropriação do sistema de escrita alfabética (SEA).

Ao final do primeiro ano do ensino fundamental, já escrevendo e lendo palavras, em função de terem compreendido como o SEA funciona e de terem dominado os valores convencionais de várias letras, nossos sujeitos continuavam com um rendimento médio inferior a $50 \%$ em quatro das nove tarefas de consciência fonêmica que foram chamados a resolver. Esta acentuada dificuldade se revelou quando eram avaliadas as habilidades de: Sintetizar fonemas para formar 
palavras (48,75\% de acertos), Produzir palavras com o mesmo fonema inicial (47,5\% de acertos), Subtrair fonemas em início de palavras (também 47.5\% de acertos) e Segmentar palavras em fonemas (17,5\% de acertos, apenas). Se considerarmos a lógica psicométrica, para eles apenas uma única tarefa foi "muito fácil", a Identificação de palavras com o mesmo fonema inicial, na qual apresentaram rendimento médio um pouco superior a 80\% de acertos. Estudos prévios feitos com crianças brasileiras (por exemplo, MOUSINHO; CORREA, 2009; LEITE, 2011; MORAIS, 2012) já tinham atestado essa "complexidade" de certas tarefas que medem a consciência fonêmica, mesmo para crianças "já leitoras".

Como nossos sujeitos tinham sido submetidos a uma didática em que aquelas e outras tarefas de consciência fonêmica ocupavam mais de $20 \%$ do tempo dedicado ao ensino de alfabetização, cabe interpretar por quais motivos continuariam apresentando resultado baixo ou mediano na maioria das provas por nós aplicadas.

Julgamos que nossas exaustivas análises qualitativas das verbalizações e das condutas observadas, quando as crianças resolviam cada item de cada tarefa, trouxeram bastante luz para avançarmos na compreensão de como refletiam sobre os segmentos sonoros das palavras em jogo. Vimos que os aprendizes: i) muito raramente pronunciavam fonemas isolados em voz alta; ii) recorriam sobretudo aos nomes das letras para resolverem variadas tarefas; iii) também raciocinavam sobre sílabas completas, em lugar de pronunciar fonemas isolados; iv) pronunciavam uma "mistura" de sílabas, letras e fonemas (ou tentativas malsucedidas de pronunciar fonemas isolados) e v) também acertavam dizendo apenas que as palavras em foco "começavam ou terminavam parecido", sem explicitar os segmentos identificados como semelhantes. Em suma, pronunciar fonemas em voz alta, porque seriam capazes de "manipulá-los", não demonstrou ser uma conduta espontânea entre nossos estudantes, o que nos leva a concluir que tal capacidade não parece ter constituído um requisito para terem alcançado uma hipótese alfabética de escrita e conseguirem ler e escrever palavras. Soares (2016) faz uma aguçada reflexão a respeito da natureza "impalpável" dos fonemas e a respeito do quanto identificar tais segmentos sonoros seria muito mais viável que realizar sobre eles outras operações metalinguísticas.

As análises de correlação entre as habilidades de consciência fonêmica de nossas crianças e suas habilidades de ler palavras, frases e textos apontaram que "refletir sobre fonemas" teria uma limitada relação com a capacidade de ler palavras (apenas duas 
das nove habilidades de consciência fonêmica correlacionaram significativamente com o desempenho em leitura de palavras). E que tal correlação seria ainda menos determinante para se ler e compreender frases e textos (em cada caso, só uma das nove habilidades metafonêmicas alcançou a significância).

O que todas essas evidências nos sugerem, quando examinamos o papel da consciência fonêmica na alfabetização?

Do ponto de vista teórico, parece-nos fundamental retomarmos uma perspectiva evolutiva, que trata a aparição de habilidades de consciência fonêmica no conjunto das habilidades de consciência fonológica e que vê o desenvolvimento das primeiras como uma consequência da capacidade de separar os significantes orais das palavras de seus significados, isto é, das propriedades físicas e funcionais dos objetos a que aquelas palavras se referem. Ora, isto implica avançar naquilo que, já no início dos anos 1980, chamávamos "superação do realismo nominal" (CARRAHER; REGO, 1981) e que detectou, inicialmente, capacidades de comparar palavras quanto ao tamanho (quantidade de sílabas, no caso do português), identificar palavras que rimam ou que começam com a mesma sílaba (e não só como mesmo fonema). Esta última habilidade - identificar palavras que começam com o mesmo fonema - é que pareceria, de fato, constituir uma condição (mas não a única!) para que crianças brasileiras compreendam "o princípio alfabético" e possam se beneficiar de um ensino sistemático das convenções grafema-fonema do português (cf. MORAIS, 2004; 2015). Mas, para lá chegar, elas refletem, anteriormente, sobre sílabas e rimas das palavras, vendo que palavras variam quanto à extensão e que se parecem ou se diferenciam por terem "pedaços", maiores que fonemas, que são iguais ou distintos.

Como já foi assinalado por Morais, A. (2012, 2015, 2019) e por Aragão e Morais (2013), defendemos também que a "compreensão do princípio alfabético" não seria garantida pelo exclusivo desenvolvimento de habilidades de consciência fonológica, sequer no nível fonêmico. Desvendar uma série de questões conceituais, apontadas por Ferreiro (1990) também seria condição necessária para uma criança avançar em suas hipóteses de escrita e desvendar, finalmente, a "lógica" alfabética de nossa notação escrita. Como assinala Ferreiro(1990), a apropriação do SEA implica compreender relações entre partes e todos orais e escritos, compreender a natureza sequencial de nossa notação alfabética e tratar as letras como classes de objetos substitutos, independentemente de variações em sua aparência gráfica(P, p, P, p, P, p são uma mesma classe). 
Um segundo grande tema de interesse para o debate psicolinguístico, apontado por nossas análises qualitativas, diz respeito ao lugar da escrita na análise dos segmentos fonêmicos. Como aponta Morais (2019), entendemos que "pensar sobre letras" não é exatamente idêntico a "pensar sobre fonemas", como tantas vezes é admitido por estudiosos da consciência fonêmica. Se, ao explicitar verbalmente letras, do ponto de vista do formato representacional (MANDLER, 1983), o sujeito demonstra estar manipulando ou identificando unidades gráficas e não sonoras das palavras, duas questões merecem esclarecimento.

A primeira indaga se algumas tarefas, habitualmente usadas na avaliação da consciência fonêmica, não exigiriam do sujeito, criança ou adulto, operar sobre imagens (orto)gráficas das palavras e, portanto, ser minimamente alfabetizado, a ponto de já ter constituído um léxico mental de palavras escritas, que poderia acessar, de forma automática, ou reconstruir, em suas mentes.

Um segundo aspecto envolvido nesse imbróglio é a necessidade de retomarmos o debate sobre o papel que a notação escrita tem no desenvolvimento da consciência fonológica, em geral, e da consciência fonêmica, em particular. Desde os anos 1980, fomos apresentados a evidências de que, o armazenamento de um léxico de imagens ortográficas afeta o modo como os aprendizes concebem a estrutura sonora das palavras (cf. por exemplo, EHRI; WILCE, 1980; TUNMER; NESDALE, 1985). Em meados daquela década pactuamos, também, um relativo consenso de que as relações entre o desenvolvimento da consciência fonêmica e o aprendizado da notação alfabética são interativas, influenciando-se mutuamente. Interpretamos, portanto, que nos resta avançar na elucidação de como a notação escrita, ou melhor, as unidades gráficas que são as letras tornam "observáveis" esses segmentos abstratos e pouco palpáveis que os estudiosos denominam "fonemas".

Recordamos que esse tipo de cobrança já era feito por Vernon (1997) e por Vernon e Ferreiro (1999) há vinte anos. Parece-nos também curioso que não se tenha dado ênfase a certa evidência do clássico estudo de treinamento e acompanhamento longitudinal de Bradley e Bryant, publicado em 1983: ao comparar os quatro grupos de crianças submetidas a diferentes tratamentos, os autores constataram que aquelas que revelaram um desempenho significativamente superior na aprendizagem da leitura tinham vivenciado a análise de rimas e aliterações em palavras, ao mesmo tempo em que eram estimuladas 
a escrever aquelas palavras com letras móveis (BRADLEY; BRYANT, 1983). Escrever e pensar simultaneamente sobre sons parecidos era mais eficiente que apenas detectar, oralmente, semelhanças sonoras!

Do ponto de vista didático, as evidências apresentadas neste artigo nos parecem trazer à arena a urgência de um debate a respeito de quais habilidades de consciência fonológica - sobre sílabas, rimas, fonemas e palavras- faz sentido promovermos na escola, desde a educação infantil, para ajudarmos todas as crianças, independentemente de sua origem sociocultural, a compreender o princípio alfabético e a se apropriar das relações grafema-fonema e fonema-grafema do português. ${ }^{3}$

Nossos dados sugerem que não faria sentido torturar crianças, obrigando-as a pronunciar os fonemas isolados de cada palavra, assim como não haveria ganhos especiais em fazê-las adicionar ou subtrair fonemas de palavras nem em fazê-las ouvir fonemas soltos para "juntá-los", reconstituindo uma palavra real. As evidências prévias obtidas por Aragão e Morais (2013), ao analisarem o baixíssimo desempenho de crianças (já com hipótese alfabética),ao responder tarefas em que eram usadas "pseudopalavras", também atesta o pouco uso desse tipo de recurso supostamente sofisticado.

Como alternativa a tais "treinamentos" de habilidades exclusivamente fonêmicas, estudos realizados em nosso país (cf. MORAIS; 2012, MORAIS; ALBUQUERQUE; BRANDÃO, 2016) têm demonstrado o quanto o emprego de atividades lúdicas, envolvendo jogos (BRASIL-MEC, 2009) ou cantigas e outros textos poéticos da tradição oral, pode fazer com que uma alta proporção de aprendizes chegue a uma hipótese alfabética, no último ano da educação infantil. Nesses estudos de intervenção, as crianças brincavam e refletiam sobre palavras maiores que outras, sobre palavras que rimavam ou que começavam com a mesma sílaba, sempre podendo, concomitantemente, ver as formas escritas daquelas palavras. E, ao lado dos gêneros da tradição oral, conviviam com um rico repertório de textos que as fazia avançar em suas habilidades de compreensão leitora e de produção de textos escritos, antes de terem alcançado uma hipótese alfabética, tal como outros pesquisadores brasileiros (cf. FONTES; CARDOSO-MARTINS; 2004; REGO, 1988)já demonstraram ser possível e adequado há bastante tempo.

Quando examinamos documentos oficiais brasileiros que buscaram e buscam normatizar o ensino de alfabetização, vemos que os direitos de aprendizagem apregoados pelo PNAIC (BRASILMEC, 2012) assumiam, explicitamente: a) o papel da escola na 
promoção da consciência fonológica em geral, aí compreendido o ensino e a avaliação de habilidades de algumas habilidades envolvendo a consciência fonêmica; b) o ensino explícito das relações grafema-fonema e fonema-grafema, nos três primeiros anos do ciclo de alfabetização, com uma clara progressão de metas a cada ano. Isso atesta o quanto aquela proposta, ao assumir uma perspectiva construtivista e de "alfabetizar- letrando", nunca abriu mão de uma política pública de ensino de alfabetização que promovesse a reflexão metafonológica e que assumisse um "ensino explícito" das convenções entre letras e sons.

$\mathrm{Na}$ contramão de tal perspectiva, a BNCC-Base Nacional Comum Curricular imposta, sem debate, pelo MECe legitimada por um Conselho Nacional de Educação desfigurado (BRASIL-MEC-2017), revelou-se bastante frágil quanto a: i) prescrever, na educação infantil, um ensino que assegure às crianças brasileiras o direito de concluírem aquela etapa tendo compreendido o princípio alfabético e desenvolvido diversas habilidades de consciência fonológica; e ii) normatizar um ensino com uma progressão no domínio das correspondências entre grafemas e fonemas e entre fonemas e grafemas nos anos iniciais do ensino fundamental. Uma outra questão que nos parece tão ou mais grave é o fato de que tal currículo, num suposto afã de garantir o ensino e o aprendizado do "código" alfabético, subtraiu em muito a dimensão do letramento, restringindo as práticas de leitura e escrita de gêneros textuais a textos curtos (BRASIL-MEC, 2017, pp. 103, 105, 109 e 111), sem prescrever, sequer, quais habilidades de compreensão leitora os aprendizes brasileiros têm direito a desenvolver até o final do segundo ano do ensino fundamental.

Ao concluir, queríamos pontuar a necessidade de avaliarmos a eficácia e a adequação de "sistemas de ensino", "apostilados" e livros didáticos que têm apostado em "métodos fônicos" como a panaceia para os problemas do ensino de alfabetização em nosso país. Recordamos que, quando fomos "ao campo", e localizamos duas professoras que buscavam seguir, cuidadosamente, o método fônico imposto por sua rede de ensino, encontramos, ao final do ano letivo, menos de $70 \%$ de seus alunos com uma hipótese alfabética de escrita e, consequentemente, sem poder ler e escrever palavras convencionalmente. Essa singular evidência sugere a adequação de avaliarmos, muito criteriosamente, os princípios e os efeitos daqueles "pacotes de alfabetização" baseados em "métodos fônicos", que só sabem ensinar de modo padronizado, do Oiapoque ao Chuí, desrespeitando as formas de ensinar e de aprender dos alfabetizadores e dos alfabetizandos. 


\section{REFERÊNCIAS}

ARAGÃO, S.A.; MORAIS, A.G. Crianças com hipótese silábica, ensinadas pelo método fônico, não conseguem resolver tarefas de consciência fonêmica. Anales del Congreso Latinoamericano para el Desarrollo de la Lectura y la Escritura. Vol. 7: 73-80, 2013

AZEVEDO, S. S. Conhecimentos fonêmicos de crianças concluindo a alfabetização. Monografia (especialização)- Faculdade Frassinetti do Recife, Pós-graduação em Alfabetização, Recife, 2011.

BRADLEY,L. BRYANT. Categorizing Sounds and Learning to Read: A Causal connection. Nature, 301, p. 419-421, 1983.

BRASIL, Ministério da Educação. Jogos de Alfabetização. Pernambuco, 2009.

BRASIL. Base Nacional Comum Curricular: Educação Infantil e Ensino Fundamental. Brasília: MEC/Secretaria de Educação Básica, 2017.

BRASIL. Ministério da Educação. Elementos conceituais e metodológicos para definição dos direitos de aprendizagem e desenvolvimento do ciclo de alfabetização $\left(1^{\circ}, 2^{\circ}\right.$ e $3^{\circ}$ anos) do ensino fundamental. Brasília. Dezembro/2012.

CAPOVILlA, A. G. S. \& CAPOVILLA, F. C. (1998). Prova de Consciência Fonológica: Desenvolvimento de dez habilidades da pré-escola à segunda série. Temas sobre Desenvolvimento, 7(37), 14-20.

CARRAHER, T. N.; REGO, L. L. B. O realismo nominal como obstáculo na aprendizagem da leitura. Cadernos de Pesquisa, São Paulo (39): 3- 10, Nov. 1981.

CAVALHEIRO, L.G.; SANTOS, M.G.; MARTINEZ, P.C. A influência da consciência fonológica na aquisição de leitura. Rev. CEFAC [online]. 2010, vol.12, n.6, pp.10091016. Epub 25 de junho de 2010. ISSN 1516-1846. http://dx.doi.org/10.1590/S151618462010005000063.

EHRI, L.C.; WILCE, L.S. The influence of orthography on readers' conceptualization of the phonetic structure of words. Applied Psycholinguistics (1):371-385, 1980.

FERREIRO, E. A escrita... antes das letras. In: SINCLAIR, H. (Org.). A produção de notações na criança: linguagem, número, ritmos e melodia. São Paulo: Cortez; Autores Associados, 1990. p. 19-70.

FONTES, M.J. e CARDOSO-MARTINS, C. Efeitos da leitura de histórias no desenvolvimento da linguagem de crianças de nível socioeconômico baixo. Psicologia: Reflexão e Crítica. 2004, vol.17, n1:83-94, 2004.

FREITAS, G.; VIDOR, C. A consciência fonológica em adultos alfabetizados. Cadernos de Pesquisa em Linguística. Porto Alegre, v.1, nº1, agosto 2005, p.99-102.

GOUGH, P.; LARSON, K.; YOPP, H. A estrutura da consciência fonológica. In: CARDOSO-MARTINS, C. (org.) Consciência fonológica e alfabetização. Petrópolis: Vozes, 1995.

LEITE. T. M. R. Alfabetização - Consciência Fonológica, Psicogênese da Escrita e conhecimento dos nomes das letras: um ponto de interseção. Recife: UFPE, 2006. 
Dissertação (Mestrado em Educação), UFPE, 2006.

LEITE, T. M. R. Alfabetização: evolução de habilidades cognitivas envolvidas na aprendizagem do sistema de escrita alfabética e sua relação com concepções e práticas de professores. Tese (Doutorado em Educação) - Universidade Federal de Pernambuco, Centro de Educação - Recife, 2011.

MANDLER, J, Representation. In MUSSEN, Paul. (ed.) Handbook of Child Pscyhology. New York: John Willey\& Sons, vol. 3, 420-494, 1983.

MORAIS, A. G. A apropriação do sistema de notação alfabética e o desenvolvimento de habilidades de reflexão fonológica. Letras de Hoje. Porto Alegre. V. 39, n 3, p. 193-206, setembro, 2004.

MORAIS, A. G. Sistema de escrita alfabética. São Paulo: Editora Melhoramentos, 2012.

MORAIS, A. G. O Desenvolvimento da Consciência Fonológica e a Apropriação da Escrita Alfabética entre Crianças Brasileiras. Revista Brasileira de Alfabetização, v. 1, p. 1-18, 2015.

MORAIS, A. G. Consciência Fonológica na Educação Infantil e no Ciclo de Alfabetização. Belo Horizonte: Autêntica, 2019.

MORAIS, A. G.; ALBURQUEQUE, E.; BRANDÃO, A. C. Refletindo sobre a língua escrita e sobre sua notação no final da educação infantil. Revista Brasileira de Estudos Pedagógicos. Brasília, v. 97, n. 247, p. 519-533, set./dez. 2016

MORAIS, A G. \& LIMA, N.C. Análise Fonológica e Compreensão da Escrita Alfabética: um estudo com crianças da escola pública. Anais do Simpósio Latino-Americano de Psicologia do Desenvolvimento. Recife, 1989, 51-54.

MORAIS, J.; CARY, L.; ALEGRÍA, J. \& BERTELSON, P. Does awareness of speech as a sequence of phones arise spontaneously? Cognition, 7, 323-331, 1979.

MOOJEN, S. (Coord.) CONFIAS- Consciência fonológica: instrumento de avaliação sequencial. São Paulo: Casa do Psicólogo, 2003.

MOUSINHO R, CORREA J. Habilidades linguístico-cognitivas em Leitores e não-leitores. Pró-Fono Revista de Atualização Científica, v. 21 (2) p. 113-8 abr.-jun., 2009.

PESSOA, A. C. R. Relação entre habilidades de reflexão metalinguística e domínio da ortografia em crianças. 2007. Tese (Doutorado em Educação), Universidade Federal de Pernambuco, Recife, 2007.

PULIEZI, S. MALUF, M. R. A contribuição da consciência fonológica, memória de trabalho e velocidade de nomeação na literatura. Boletim Academia Paulista de Psicologia 2012, 32 (Data de consulta: 22 de abril de 2019).Disponível em: < http:/ / www.redalyc.org/articulo. oa?id=94623639013 > ISSN 1415-711X

REGO, L.L.B. Descobrindo a língua escrita antes de aprender a ler: algumas implicações pedagógicas. In KATO, M. (org.) A concepção de escrita pela criança. Campinas: Ed. Pontes, 1988. (pp. 105-135).

SANTOS, M. MALUF, M. R. Consciência fonológica e linguagem escrita: efeitos de um programa de intervenção. In: Educar em Revista. Curitiba, PR: Ed. UFPR, n. 38, set./dez. 2010.

SOARES, M. B. Alfabetização: a questão dos métodos. São Paulo: Contexto, 2016. 
STANOVICH, K. E. Mathew effects in reading: some consequences of individual differences in the acquisition of literacy. Reading Research Quarterly, XXI:360-407, 1986

TUNMER, W.E.; NESDALE, A.R. Phonemic segmental skill and beginning reading. Journal of Educational Psychology, 77:417-427, 1985.

VERNON, S. Escritura y conciencia fonológica en niños hispanoparlantes. Infancia y Aprendizaje. Madrid, nº 81, p. 105-120, 1997.

VERNON, S; FERREIRO, E. Writing Development: a neglected variable in the consideration of phonological awareness. Harvard Educational Review, vol. 69, $\mathrm{n}{ }^{\circ} 4$, pp. 395-416, 1999.

\section{NOTAS}

1 Voltaremos a esse ponto em nossas conclusões. Parece-nos preocupante que, apesar de ambas as turmas terem mais de 20 alunos, não tenhamos encontrado um mais alto percentual de crianças já com hipóteses alfabéticas de escrita em cada grupo-classe.

2 Considerando o baixíssimo resultado encontrado por Aragão e Morais (2013), ao solicitar que crianças adicionassem ou subtraíssem fonemas de palavras inventadas, optamos por não incluir tais tarefas. Naquele estudo de 2013 vimos que os aprendizes não compreendiam como deviam operar, mesmo vivendo a apresentação de itens de exemplo e de itens de treino com feedback. No caso da adição de fonemas em palavras inventadas, elas tendiam, por exemplo, a adicionar outro fonema à palavra escutada ou produziam uma palavra com o fonema que o adulto tinha pronunciado isoladamente.

3 Obviamente, a questão também se aplica ao domínio da clínica psicopedagógica, psicológica e fonoaudiológica, que aplica "baterias" de avaliação da consciência fonológica, para diagnosticar e elaborar laudos sobre a origem das dificuldades de crianças em se alfabetizar. Em tais baterias, a introdução de tarefas que parecem exigir pensar sobre a forma (orto)gráfica das palavras (e não só pensar sobre segmentos sonoros) e a indistinção entre tarefas no nível fonêmico e outras (que envolvem rimas e sílabas), quando se trata de calcular escores globais dos indivíduos, nos parecem merecer uma séria revisão.

Submetido: 01/05/2019

Aprovado: 17/10/2019

Contato:

Silvia de Sousa Azevedo Aragão, Rua Marquês do Paraná, n¹60, Apto 704|Espinheiro Recife |PE |Brasil CEP 52.021-050 
APÊNDICE 1. ESCRITA DE PALAVRAS PRODUZIDA POR JOÃO, CRIANC̣A PARTICIPANTE, QUE É CITADA NA EPÍGRAFE DESTE ARTIGO

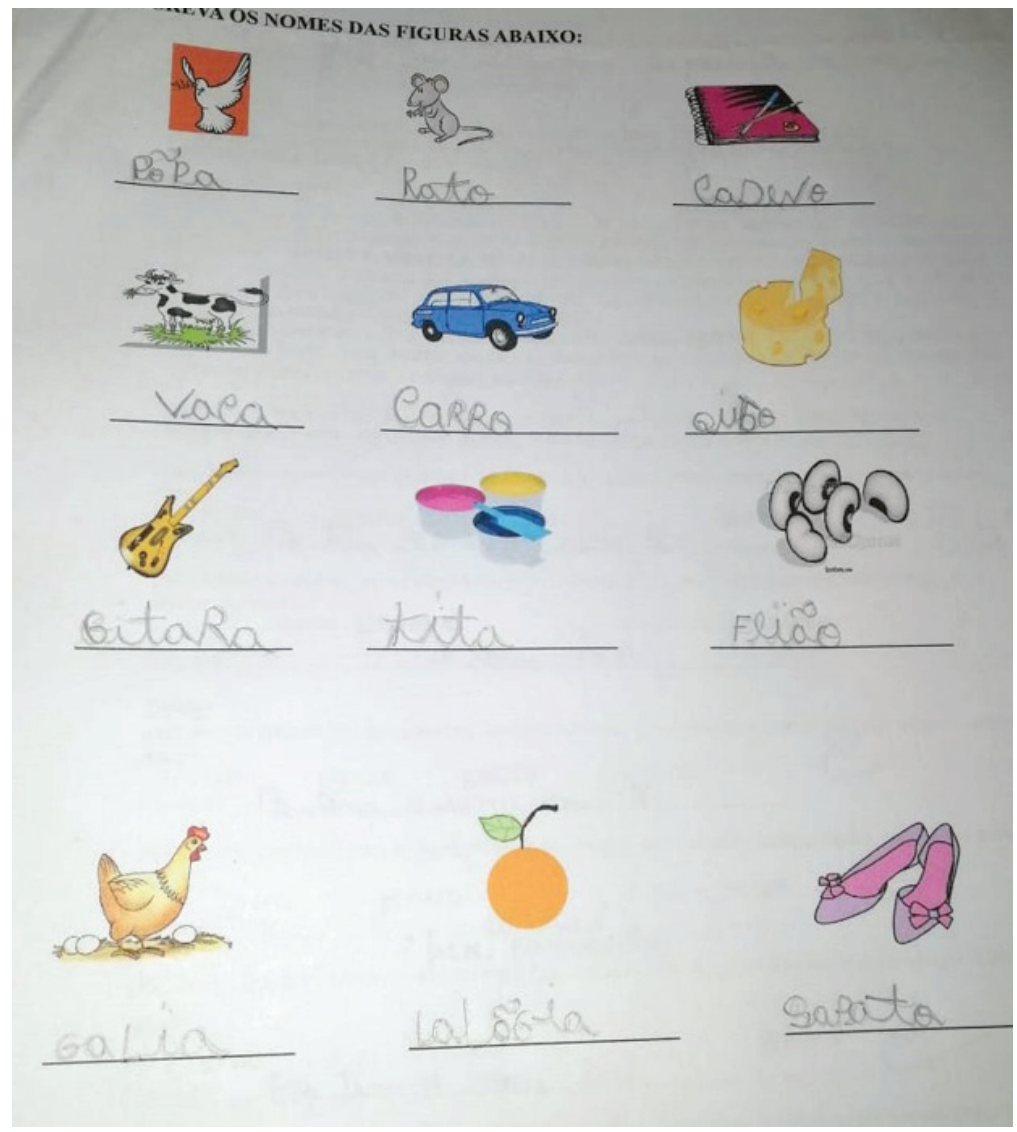

